\title{
Romatoid artrit tedavi prensipleri: Neye geçiş yapalım?
}

\section{Rheumatoid arthritis treatment strategies: Switch or swap?}

Gonca Karabulut ${ }^{1}$ Zeynep Özbalkan Aşlar ${ }^{2} \oplus$

Ege Üniversitesi Tıp Fakültesi, İç Hastalıkları Anabilim Dalı Romatoloji Bilim Dalı, İzmir, Türkiye Hitit üniversitesi Tıp Fakültesi, İç Hastalıkları Anabilim Dalı, Romatoloji Bilim Dalı, Çorum, Türkiye

Öz

Romatoid artrit erişkinde en sık görülen inflamatuar artrittir. Remisyon veya düşük hastalık aktivitesi sağlanana kadar tedavi modifikasyonları yapılmalıdır. Gelecekte yapılacak daha kapsamlı çalışmalar ile bireyselleştirilmiş tedavilerin geliştirilmesi mümkün olabilecektir.

Anahtar Sözcükler: Romatoid artrit, tedavi, yönetim.

\begin{abstract}
Rheumatoid arthritis is the most common inflammatory disease in adults. Modifications for treatment should be made until reaching the goals. Detailed studies should be planned for developing tailoring therapies.
\end{abstract}

Keywords: Rheumatoid arthritis, treatment, management.

\section{Giriş}

Romatoid artrit (RA) tedavisi komplekstir. Gün geçtikçe farklı sınıflardan farklı etki mekanizmaları olan ilaçlar gündeme gelmektedir. Her geçen gün ilaç dışı tedaviler de önem kazanmaktadır. Hasta eğitimi, egzersiz, fiziksel ve uğraş tedavileri bugün daha ön plana çıkmaktadır. Koroner ateroskleroz gibi mortal nedenler arttığı için riski azaltacak yaklaşımlar; sigara, hiperlipidemi, hipertansiyon ve obezite ile savaş daha fazla önem kazanmaktadır.

Öncelik; ağrıyı azaltıp şişliği indirerek inflamasyonu kontrol altına almaya çalışırken hastayı rahatlatmaktır. Oral veya intraartiküler steroid uygulaması semptom ve bulguların alevli olduğu dönemde temel etkili ilaçların etkisi çıkana kadar köprü görevi görmektedir. Oral steroid kısa dönem kullanılmalı (3-4 ay) ve en kısa sürede azaltılarak kesilmelidir. Uzun dönem tedavide temel etkili ilaçlar ile tedaviye devam edilmelidir.

\section{Hedef;}

- Ağrının düzelmesi,

- İnflamasyonun baskılanması,

- Eklem yapılarının korunması,

- Eklem fonksiyonlarının korunması,

Sorumlu yazar: Gonca Karabulut

Ege Üniversitesi Tıp Fakültesi, İç Hastalıkları Anabilim Dalı

Romatoloji Bilim Dalı, İzmir, Türkiye

E-posta:gonca4us@yahoo.com
- Sistemik tutulumların önlenmesi,

- Remisyon veya mümkün olan en düşük hastalık aktivitesini yakalamaktır.

Remisyon, herhangi bir aktif hastalık belirtisinin olmaması durumunu ifade eder ve birtakım klinik ve laboratuvar parametrelerden oluşur. Tedavi hedeflerine ulaşamayan hastalar da mevcuttur. TNFa inhibitörü alan RA hastalarının 2/3'si altı ay içerisinde EULAR iyi yanıtına ulaşamamaktadır $(1,2)$. \%5-45 oranında sürdürülebilir klinik remisyon görülmektedir (3). Hastalarda sekonder yanıt kaybı da olabilir.

Hasta tarafından bildirilen sonuçlara göre süren hastalık yükü önemlidir (4). Hastaların \%848 'inde yetersiz hastalık kontrolü görülebilir (5).

Bazı hastalarda biyolojik hastalık modifiye edici ilaç (bDMARD) kullanımında kısıtlamalar olabilir. Özellikle enjeksiyon yeri reaksiyonları sorun yaratabilir. Optimal tedavi, metotreksat (MTX) ile kombinasyondur.

\section{Treat-to-target yaklaşımı nedir?}

Bu yaklaşımın merkezinde; karara varmayı ortak yol haline getirme, sıradan hasta takibinde remisyon veya düşük hastalık aktivitesini hedefleme vardır. 
Tüm ilaçlarda hastalık süresi uzadıkça ve ilaca maruziyet arttıkça etki kaybı meydana gelir. Daha önce metotreksat (MTX) kullanmamış hastalarda tüm biyolojikleri ve hedeflenmiş (targeted) sentetik DMARD'ları MTX ile birlikte kullandığımız zaman etkinlik artar. MTX'ten önce bu tedavilere başlamamak gerekir. Başlangıç tedavisi olarak önerilmezler. Hedefe yönelik tedavilerde üç ayda bir tedavi değerlendirilir. Altıncı ayda semptom\%50 kaybolmamışsa tedavi değişikliği yapılır. Bu yaklaşım ile eklem hasarı engellenebilir.

Etkinliği verimli hale de getirmek gerekir. Remisyon sağlanınca bDMARD ve hedefe yönelik sentetik DMARD (tsDMARD)'da doz azaltılmaya başlanır. Hasta altı ay boyunca remisyonda kalmış ise doz azaltmaya geçilebilir. İlaç kesilince relapslar olabilir. Doz azaltılarak veya uygulama süresi uzatılarak ilaç kesilmesi yoluna gidilmelidir. Uygun şekilde ilaç kesildikten sonra alevlenme olursa yine aynı ilaca başlanabilir. Enfeksiyon, tüberküloz, demiyelizan durumlar (anti-TNF), herpes zoster (JAK), intestinal perforasyon (IL-6) önemli yan etkiler olarak akılda tutulmalıdır.

Kişiselleştirilmiş tıp; hastanın ihtiyacına (hastalığın durumuna) göre tamamen kişiselleştirilmiş bir tedavi yaklaşımı çizilmesidir. Her hastayı kendi genetik, farmakogenomik özellikleri ile değerlendirerek, bireysel imzasını belirleyerek tedavi seçimini bu imzaya göre belirlemek temeldir ve dayanağı da kişilerin aynı ilaca farklı yanıtlarıdır.

Romatoid artrit örneğinde genel olarak mevcut ilaçlar hastaların çoğunun ihtiyacına cevap verse de, bazılarında beklenen etkiyi göstermezler. Yüksek hastalık aktivitesi devam eder, kalıcı eklem hasarı oluşur ve ön görülen riskler artar. IYI/KÖTÜ cevabı ayırt edebilmek için biyobelirteçlere intiyaç vardır ve hala ideal biyobelirteç bulunamamıştır. Genetiği biyobelirteç olarak kullanmanın bazı avantajları vardır (sabittir ve ölçümle değişim göstermez, epigenetik faktörler gibi değişken değildir). Genetik değişkenler hastalığın sebep olduğu hasarı tam açıklayamayabilir ve tedavi stratejisini geliştirmede zorluğa neden olabilir (6).

Transkriptomik ve epigenomik yaklaşımda örneğin metillenmiş DNA'yı biyobelirteç olarak kullanıp TNF inhibitör tedavisine cevabı lokusa özel skorlamalarla ölçmek genetik çalışmaların hedeflerindendir.

Temelde bu çalışmalar hastalıkların biyomekaniğini de daha kolay anlamamızı sağlayacaklardır. Bu sayede biyobelirteçler daha iyi ortaya konacak, tıpkı terzi eli değmişçesine kişiye özel tedavi seçenekleri geliştirilecektir ve hastalık remisyona sokulabilecektir.

Biyolojik ilaçların ilk veya ikinci sırada kullanıldığı hastalarda, mevcut tedavilerle ortalama yanıt \%30 olmaktadır. Kullanım süresi uzadıkça yan etkiler de ortaya çıkmakta ve tedavi kesilmektedir.

EULAR stratejilerinde bir bDMARD veya tsDMARD başarısız olursa diğer bir bDMARD veya tsDMARD'a geçmek önerilmektedir. AntiTNF başarısız olursa ikinci bir anti-TNF'ye geçilmesi önerilmektedir.

Gerçek hayatta ikinci anti-TNF ajana geçildiğinde başlangıçta yanıt daha az olmakta ve etki daha kısa sürede azalabilmektedir. Ancak halen standardize bir metot yoktur ve tartışılmaktadır.

\section{Sonuç}

Özet olarak güvenlik verileri incelendiğinde bir ajanın diğerine üstünlüğü bulunmamaktadır. Gerçek yaşam verilerinde her ne kadar bazı yayınlarda "adalimumab, etanersept daha iyi bir switch ajanıdır" dense de non-TNF biyolojik ajanlar analize dâhil edildiğinde hepsinden daha iyi bulunmaktadır.

Hastaların tedavisinde global olarak sekonder sonlanım noktalarına varış araştırılırken kar/zarar hesabı da yapılmalıdır.

\section{Kaynaklar}

1. Smolen JS, Aletaha D, Bijlsma JW, et al. T2T Expert Committee. Treating rheumatoid arthritis to target: recommendations of an international task force. Ann Rheum Dis 2010; 69 (4): 631-7.

2. Smolen JS, Breedveld FC, Burmester GR, et al. Treating rheumatoid arthritis to target: 2014 update of the recommendations of an international task force. Ann Rheum Dis 2016; 75 (1): 3-15.

3. Smolen JS, Landewé R, Bijlsma J, et al. EULAR recommendations for the management of rheumatoid arthritis with synthetic and biological disease-modifying antirheumatic drugs: 2016 update. Ann Rheum Dis $2017 ; 76$ (6): 960-77.

4. Singh JA, Saag KG, Bridges SL Jr, et al. American College of Rheumatology. 2015 American College of Rheumatology Guideline for the Treatment of Rheumatoid Arthritis. Arthritis Care Res 2016; 68 (1): 1-25.

5. Upchurch KS, Kay J. Evolution of treatment for rheumatoid arthritis. Rheumatology (Oxford). $2012 ; 51$ (Suppl 6): vi28-36.

6. Acosta-Herrera M, González-Serna D, Martín J. The potential role of genomic medicine in the therapeutic management of rheumatoid arthritis. J Clin Med 2019; 10; 8(6). pii: E826. doi: 10.3390/jcm8060826. Review. 